\title{
AUTOMATED QUEUING SYSTEM ON PERFORMANCE OF SELECTED STATE-OWNED COMMERCIAL ENTITIES IN KENYA: A CONCEPTUAL PAPER
}

\author{
Judith Ochieng ${ }^{1 \bowtie(D)}$, Dr. Henry Kegoro $2 \square$ (iD \\ ${ }^{1}$ Lecturer, Kiriri Women's University of Science and Technology, Kenya
}

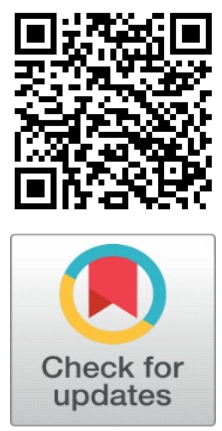

Received 1 September 2021

Accepted 15 September 2021

Published 30 September2021

\section{CorrespondingAuthor}

Dr. Henry Kegoro,

hongoto@yahoo.com

DOI

10.29121/granthaalayah.v9.19.2021. 4220

Funding: This research received no specific grant from any funding agency in the public, commercial, or not-for-profit sectors.

Copyright: (C) 2021 The Author(s). This is an open access article distributed under the terms of the Creative Commons Attribution License, which permits unrestricted use, distribution, and reproduction in any medium, provided the original author and source are credited.

\section{ABSTRACT}

Despite the vital role of automated queuing system on organizational performance from human resource management literature, researchers have paid little attention on stateowned commercial entities and more specifically in Kenya. Studies have revealed controversial findings on the link between automated queuing system and organizational performance thus the need for further studies to bridge the knowledge gaps. The general objective of this study will be to examine the influence of automated queuing system on performance of selected state-owned commercial entities in Kenya. Three specific objectives will be examined. The first objective will be to determine the extent of adoption of automated queuing systems in the selected State-owned entities in Kenya. The second objective will be to establish the influence of automated queuing systems on performance of selected State-owned entities in Kenya. The third objective will be to assess the challenges experienced by selected State-owned entities in Kenya when implementing automated queuing system policies and the fourth objective will be to ascertain ways of mitigating the challenges of implementing automated queuing system policies in State-owned entities in Kenya. This study will be informed by Queue management theory and technology acceptance theory. Exploratory research design will be utilized in this study. Desktop research analysis will be adopted. Published materials including peer-reviewed journals, conference papers, theses and reports relevant with the topic of the current study will be reviewed. Findings, conclusions and recommendations of this study will be derived from findings of previous empirical studies. Recommendations will be made in accordance with recommended protocols and guidelines of statistical literature. Further research will be recommended in other areas using different methodologies to facilitate collaboration of the results.

Keywords: Automated Queuing System, Organizational Performance and State-Owned Commercial Entities.

\section{INTRODUCTION}

Environmental turbulence, technological change and competitiveness, businesses are rethinking agile practices that can provide them with a strategic advantage to improve operating efficiency Ade, Namusonge \& Sakwa, (2019). Queues also known as waiting lines are very common where certain market conditions demand that customers wait in line for the operation, such as in the banking halls, ATM machines, hospitals, supermarkets, restaurants, government and public service offices, airports and even public transport among others. Retail customer care centres as one the service providers have to deal with queues on a daily basis. Modern technology proliferations have enabled service providers to incorporate many different technologies into their service delivery. 
These technologies have enables service-oriented companies who faced difficulties on how to deal with lengthy queues to manage their customers in efficient way. According to Uddin et al. (2016), inappropriate management of such queues will cause stress and tension amongst customers and lead to reduced employee satisfaction. It is also important to note that customers tend to move toward others service companies offering quality services.

Over the years, the use of computer technology to automate service delivery has expanded in scope and depth. Additional automated services including ministate delivery, payment processing and business process automation are some of the examples showing the changing existence of computer-aided automation in the service sector Marinkoric \& Obradovic (2015). Due to the difficulties in forecasting customers' arrival pattern for service accurately and/or the time needed to deliver service to each customer, it is very difficult to make accurate decisions about the capacity offered. Customers can be left confused about which line to stand in or what counter to go to when called and disturbed by the noisy crowded environment Yechiali (1995). The common experience in Kenya is that most retail customer care shops do not have the adequate facilities and capacities in terms of work force to serve the large number of customers they receive without causing much delay on the part of the customers. The customers however, have always been desirous of spending the least possible time within the customer care shops seeking services however these desires. Agyei et al. (2015)

\subsection{AUTOMATED QUEUING}

In computer systems, queues are very common. This helps to calculate one or more service facilities from the server. When a client in the queuing scheme is served, he leaves however, if the system service is busy, then the customer goes into the computer waiting system directly. Smith, \& Kerbache (2017). According to Parimula and Palaniammal (2014) queue arises when demand exceeds the service provider's current ability to the extent where consumers are unable to provide immediate service on arrival. Over the years, the use of computer technology to automate delivery of service has grown in scope and depth. Examples of the emerging existence of computer-aided automation in the service sector include additional automated services including mini-state delivery, payment processing and business system automation (Marinkoric \& Obradovic, 2015).

Uddin et al. (2016) explains that most companies offer queue management system for controlling queues of people in various situations and locations in the queue area. For a small space and quick flow, most of the methods used are manually employed. Automated queue management system, on the other hand, deals for a larger space and dynamic flow. They further state that there are two separate queue management systems have been developed EQC system-1 and EQC system-2. EQC system-1 show token number and service counter number while EQC system-2 shows the token number individually in each service counter with different displays.

A queuing problem occurs when the facilities' current service rate falls below the actual customer service rate. Studying how the lines form and how to manage them is called Queuing theory, in broader terms, queuing theory is concerned with the mathematical modeling and analysis of systems that provide service to random demands which examines every part of the waiting line to be served, including the process of arrival, operation, number of servers, number of system locations and number of customers. The first problems of queuing theory were raised, published and published by A.K. Erlang in 1909. The first congestion problems were in the beginning of 20th century. Mwangi and Ombuni (2015) 
There are two types of queues, which are structured and unstructured queues. Structured queue is a queue in a fixed form and people that included are in predictable position. We can see this at supermarket paying counter and some other retail locations such as banks and post offices. This type of queue systems often being set up to manage ticket ranking for a service with identification and thus enable a stress-free waiting. Some of this system is planned reception by appointment or remotely rank allocation on Smartphone or through SMS. Whereas, unstructured queue is where people form a queue in unpredictable and varying locations and directions. This is often the case in some forms of retail, taxi queues, ATMs and at period of high demand Titarmare and Yerlekar (2018).

\subsection{EMPLOYEE PERFORMANCE}

The phenomenon of employee performance is a multidimensional construct and an extremely vital criterion for determining organizational success or failure. Employees are the blood stream of any business and are the most valuable assets of every organization as they can make or break the organization's reputation and can adversely affect profitability Sendawula (2018). According to Men (2015), engagement is characterized by energy, absorption, involvement, efficacy, vigor, dedication, enthusiasm and a positive state, which are described as catalysts for employee performance. Academics and practitioners tend to draw conclusions about performance management based on erroneous or obsolete knowledge Gorman, Cunningham, Bergman, \& Meriac (2016).

The process of performance management involves a process where a company, organization or institution creates a working environment that empowers employees to work to the best of their abilities. The process employed by an employer to accomplish this often varies from business to business. Despite these variations, the cycle of performance management typically includes some form of target setting, performance assessment / review, and reward. Additionally, instruction is given during the whole cycle (Madison, 2016). Performance management refers to the wide variety of systematic trials, strategies, practices, and initiatives to help staff boost their performance Denisi \& Murphy (2017). Performance management involves monitoring the actions of the staff, based on calculated performance outcomes. It is therefore critical to design an appropriate performance management framework to assess what constitutes good performance and how the various dimensions of high performance can be measured (Nzomoi (2017)

Markos and Sridevi (2010) argues that organizations need to focus on factors which contribute well to improving the performance of employees. This is because the success of workers is directly related to the organization's achievements. The performance of employees indicates their efficiency and productivity leading to the achievement of organizational goals through their positive contribution as the performance of the employees ultimately results in the overall performance of the organization (as cited in Dahkoul (2018). As a source of strategic advantage, they concentrate on the utilization of their human capital (HR), in particular on employee performance (EP) as cited by Diamantidis and Chatzoglou (2019).

Performance management is concerned with the overall objective of enhancing organizational performance by dealing with the difficulty companies' face in identifying, assessing and stimulating employee performance. It is a way of fostering superior performance through the communicating objectives, identifying the roles within the competence structure necessary and establishing achievable benchmarks Chandra and Saraswathi (2018). The performance of employees 
depends on their inner satisfaction with their work. If workers are happy with their work and the organisation, they are more interested in doing well towards achieving the organizational goal Dahkoul (2018). In improving employee performance, learning organizations play an important role by providing their employees with training and development Gitongu et al. (2016). In addition, employee performance appraisal management principles often play a vital role in enhancing employee performance as they include the representation of real performance and its compliance with the benchmarks.

Dealing with rapid technological shifts, stakeholder demands and business demands depends on reducing the difference in the attitude of employees as an underpinning factor in achieving the organization's smart goals Shah et al. (2017). Isaac et al. (2017) show that workers strongly accept that the introduction of the internet in their work enabled them to enhance the task process, the acquisition of education and the efficiency of their communication, leading to improved performance of individuals and organizations. Alzghoul et al. (2018) urge the workplace environment to have a positive effect on workers by improving job satisfaction, job participation and job efficiency by developing creativity and innovation. Alzghoul et al. (2018) also clarified that by providing their workers with an innovative atmosphere and opportunities to think and behave differently, companies will outperform their competitors.

\subsection{THE TELECOMMUNICATION SECTOR IN KENYA}

\subsubsection{RESEARCH PROBLEM}

\subsubsection{RESEARCH OBJECTIVE}

The main objective of this study is to establish the effect of automated queuing system on employee performance.

Specifically, this study seeks to address the following objectives:

1) To establish the role automated queuing system on service access time

2) To determine the effect of automated queuing system customer experience

3) To assess the effect of automated queuing system on

4) To find out the effect automated queuing system on

\subsection{VALUE OF THE STUDY}

\section{THEORETICAL REVIEW}

\subsection{INTRODUCTION}

This chapter discusses theories upon which queuing management is anchored. While the queuing theory is the overarching theoretical basis for the study, social exchange theory and application of the theory of goal setting further brings out the performance management practices. 


\subsection{THEORETICAL UNDERPINNINGS}

\subsubsection{QUEUE MANAGEMENT THEORY}

In 1909, Erlang engineered Queuing theory. The principle of queuing has been primarily founded in the sense of telephone traffic. Queuing theory is a subset of probability theory used to explain the more complex mathematical models for lines or queues waiting. Queuing theory is believed to use queuing models to describe the different types of queuing processes that exist in practice. The models allow an acceptable balance to be found between the cost of service and the waiting number. In a broad range of circumstances that can be encountered in health care, engineering, and operations science, queuing models find applications Gross and Harris, (1998)

A queue management system is the arrangement of queues of individuals within retail or public sector department. It can be either reactive through a scheme that can coordinate the current queue or proactive through the collection method of queue management statistics, so that patterns can be detected and anticipated. Individuals who enter the queue in a standing line queue are directly or issued with a ticket to the next location by the machine. Customers are taken out of the standing line queue with a ticket system, which will give customers convenience and less hassle as well as their turns are not ignored. Agyei et al. (2015)

In 1904, the Danish engineer Agner Krarup Earlang first introduced the queuing principle to help assess power requirements for Danish telephone systems. Since then, it has been used and implemented in a wide variety of service sectors, including airline scheduling, mobile call centres, computer networking and health systems administration. Its applicability has often been used to validate complex simulator models, to build easy-to-implement models that endorse narrow alternatives in the initial stages of system design, to provide insights into the meaning and effect of variability in development, to propose alternative ways to structure a system and to assign tasks to people and machines. Therefore, queuing theory is concerned with the mathematical formulation and research of waiting lines that deal with the simulation and analysis of processes that meet random demands. Peter and Sivasamy (2019). The theory of queuing is key to this study as it aligns with the reliability of the automated queue management system. The ultimate aim of the queuing systems study is to understand the actions of their underlying mechanism so that management can make informed and intelligent choices.

\subsubsection{GOAL SETTING THEORY}

Edwin Locke put the goal-setting theory of motivation forward in the 1960s. This theory states that the setting of goals is basically related to the success of tasks. It notes that clear and demanding targets lead to higher and better task performance along with adequate feedback. Edwin Locke and Gary Latham (1990) defined a goal as simply as what the person actively tries to do. Locke and Latham argue that the way one experiences one's value decisions is psychological. That is, one's principles produce a motivation to do things that are aligned with them. The theory of goal setting Locke \& Latham, (1984) is based on the simplest of introspective insights, namely, purposeful intentional human actions. The interests of the individual govern it. Nonetheless, objective direction characterizes the behavior of all living beings, including those of plants. The definition of goal-directed action is therefore not limited to conscious action. The goal setting theory predicts, describes and 
affects the job performance and satisfaction of an employee, according to the highperformance period, which causes the devotion of employees to the organization Latham \& Locke (2007).

According to Yurtkoru et al. (2017), the theory of goal setting is incorporated into a longitudinal high-performance loop that provides a structure to understand motivation more thoroughly. Job satisfaction influences organizational engagement, and job dissatisfaction leads to a reduction in employee engagement with the company. Organizational performance relies on individual performance or, in other words, its output will lead to organizational performance, which implies that the conduct of corporate participants, both individually and in groups, gives control over organizational performance because motivation will affect organizational performance paais and Pattiruhu (2020). This theory was essential for this study since provides clear guidelines for measuring employee performance.

\subsubsection{DIFFUSION OF INNOVATION THEORY}

Theory of the Diffusion of Creativity (DOI), created by E.M. Rogers, in 1962, was one of the oldest social science theories. It originated in communication to illustrate how an idea or commodity gains popularity over time and diffuses (or spreads) through a particular population or social structure. The relative benefit, in Rogers' view, is the extent to which a specific group of users perceive innovation as better than the idea or practice it replaces (Rogers (1995). The greater the organization's perceived relative advantage of innovation, the quicker the level of its adoption will be Rogers (2003). The comparative benefit may be financial or non-financial. The comparative benefit can be financial or non-financial. In economic, social prestige, comfort, and pleasure terms, the extent of the benefit may be measured. Diffusion is a social process that occurs among people in response to learning about an invention, according to Dearing (2018). Diffusion includes an invention that is shared among the participants of a social structure over time through certain networks.

Diffusion is a social process that happens in response to learning about an innovation among individuals. Diffusion in its classical formulation implies an innovation that is transmitted among the participants of a social structure through certain networks over time. When an individual hears about an innovation that they think can have major implications for them or those they serve confusion about how to react normally leads to a quest for additional details, so that the potential adopter can better determine whether the qualities of the innovation warrant further exploration. Dearing of Dearing (2018)

\subsection{QUEUE MANAGEMENT SYSTEMS}

Customer Flow Management controls customer flow and their experience from initial interaction to delivery of final service. There are many stages in the process, including pre-arrival, arrival, queuing or waiting, serving, post-serving and handling. A queue management system can be defined as the management of queues of people within retail such as supermarkets, customer care outlets or public sector such as airports. It can be either reactive through a system that can coordinate the current queue or proactive via the collection system of queue management statistics, so that patterns can be detected and predicted. Titarmare and Yerlekar (2018).

In a system involving clients arriving for a product or service, a waiting line exists, queuing occurs when the service is not immediate, and customers leave the queue once they are been served. The queuing theory lays the basis for discovering 
the right solution for queue management. Traditional queuing methods include linear queues where customers physically wait in line. It is also the most common method of waiting and handling queues. Linear queues have many variations: Single Queue Service Point (SQSSP) This variation provides clients with a first-in-first-out model in the order in which they arrive. Multiple Queue Points (MQMSP) which provides customers with variation segments based on their service needs in order to differentiate those requiring longer service times from those with smaller requirements. Single Queue Multiple Service Points (SQMSP) that logically distribute services and prioritize customers to join the queue first. Ndung'u et al (2018)

For sustainable operational performance and success of any organization, Control of different capacities, such as financial capital, technical initiatives and information management, is considered to accelerate organizational competitiveness not only in the local context, but also in the global context. (Alhadid,2016). According to Kwamboka (2016), organizational effectiveness can be influenced by the introduction of suitable technologies and companies can only succeed in the 21st century by implementing modern technology.

\subsection{TYPES OF QUEUES}

Waiting not only creates inconvenience, but also frustrates the everyday lives of citizens. Unmanaged queues are also counterproductive to the efficient operation of service networks and contribute to a number of other administrative issues. In fact, since waiting has become part of daily life, queuing theory has become a valuable instrument for operations managers. In human endeavors, queuing theory has many implications, some of which include: telephony; manufacturing; inventory; supermarkets; electronic and information communication systems and networks; call centers; hospitals, banking; (Gumus,2017)

There are two types of queues, namely, structured queue and unstructured queue. The structured queue is in a fixed form and there is a predictable position for people who are included. We can see this at a pay counter in a supermarket and several other retail places such as banks and customer service centres for mobile retail. These kinds of queue systems are often set up to handle ticket ranking for an identification service and thus allow a stress-free waiting process. Unstructured queues are where individuals form a queue in unpredictable manner and at various locations and directions. Such queues are evident in certain cases such as some forms of taxi queues, ATMs and in certain instances at a time of high demand. Titarmare and Yerlekar (2018). A basic queuing model is defined in terms of the arrival processes, service mechanisms and the queuing discipline, the arrival mechanism describes the probabilistic framework of the manner in which a service's demands occur over time. The service mechanism determines the number of servers and the probabilistic structure of the time needed to attend to the client. Queue discipline describes the order in which the queue service chooses waiting customers. Uddin et al. (2016).

\subsection{EMPIRICAL LITERATURE}

Kiplagat et al. (2020). Carried out a study of National Cement Company Ltd in Kenya. The study aimed to determine the Influence of automated Queue Management System Optimization on the performance of National Cement Company Limited in Kenya. Data was collected using a questionnaire and interview guide among 105 staff of the company. Both qualitative and quantitative methods 
were used to analyse the data. The findings revealed that reliability and flexibility level; security level and staff training automated Queue Management systems positively influence the performance of the National Cement Company.

Peter and Sivasamy (2019) carried out a study on Queuing Theory Techniques and Its Real Applications to Health Care Systems - Outpatient Visits. The study focused on waiting times for patients within the OPD until their transfers to inner wards are long and the allocation to the wards. The study employed a randomized most idle routing algorithm. The algorithm appears to be fair as it chooses a server out of all idle servers at random and does not require any information on arrival rates to the system, pool sizes, or service rates at the time of rooting the decision. The study revealed that physical, psychological and emotional feelings that affect patient's perception on the waiting experience can be managed through better understanding of the techniques of Queuing theory and various measures associated with patients waiting time, then hospital managers can make decisions that have a beneficial impact on the satisfaction of all the stake holders. The study confirmed that Proper application of this effective management tool can yield impressive results.

Cowdrey (2018) in their study titled Applying Queuing Theory for the Optimization of a Banking Model were focused to investigate waiting times at banking firms to design a system to optimise the overall banking experience. Queuing analysis and queuing theory were be investigated and applied in order to improve customer experience whilst maximising profits. Different queuing strategies were implemented using waiting time as a performance measurement. In order to find the most efficient solution the following queuing methods were be investigated; FIFO, LIFO, SJF, most profitable job first and priority queues. The study found out that a queuing system for a bank can be improved. The FIFO method serves the highest number of customers; the LIFO method will have the shortest waiting time for slow arrivals, but dissatisfy customers. The SJF method has the shortest waiting time and highest customer satisfaction; priority queuing and most profitable job first can be implemented to boost profits of the bank. The study concludes that SJF method should be implemented at peak hours, while the most profitable job first scheme should be implemented at off-peak hours. Thus, using the queuing methods reduced the waiting time and improved customer satisfaction, whilst improving profits for a banking firm.

Ahmed (2016) carried out a study on Automated Queue Management System. The study focused on the banks queuing system, different queuing algorithm approaches which are used in banks to serve customer and the average waiting time. The study utilizes two different queue control systems where several processes undergo and is controlled by Intel Galileo Microcontroller that is softwarecompatible with the Arduino software development environment. The systems were then tested under different conditions to evaluate its performance. The study found out that the new approach of using automated queuing system to manage queues decreases the average waiting the time compared to the ordinary queuing system.

Mwangi and Ombuni (2015), carried out an Empirical Analysis of Queuing Model and Queuing Behaviour in Relation to Customer Satisfaction at Jkuat Students Finance Office. The study used questionnaire with 384 respondents. The study found out that the students wait in the queue for 33.4 minutes to be served which was a long period of time to wait to be served. It therefore implied that the queuing system in use was not efficient since it created a queuing problem to such an extent that some students chose to jump the queue to solve the problem while others 
abandoned the queue and coming back the same day mainly males but females abandon the queue completely only to come for the service another day.

Agyei (2015) did a study on Modeling and Analysis of Queuing Systems in Banks. This study attempted to find the trade-off between minimizing the total economic cost (waiting cost and service cost) and the provision of a satisfactory and reasonably shortest possible time of service to customers, in order to assist management of the bank in deciding the optimal number of tellers needed. Data was collected through observations, interviews and by administering of questionnaire and was formulated as multi-server single line queuing model. The data was analyzed using both TORA optimization tools and descriptive analysis methods. It evaluated the performance assessments of various queuing systems. The study found that, in terms of average waiting time and overall economic costs, the use of the five-teller system was better than a four or six-teller system.

\subsection{TABLE- SUMMARY OF THE LITERATURE REVIEW}

The table below summarizes the reviews literature relating to this study. It gives the author for the study, the title of the study, the research findings and the knowledge gap which the study sought to bridge.

\begin{tabular}{|c|c|c|c|c|}
\hline AUTHOR & YEAR & $\begin{array}{c}\text { RESEARCH } \\
\text { TOPIC }\end{array}$ & RESEACH FINDING & KNOWLEDGE GAP \\
\hline $\begin{array}{l}\text { Kiplagat, J., } \\
\text { Kamaku, P. W. } \\
\text { \& Paul, S. N. } \\
\text { (2020) }\end{array}$ & 2020 & $\begin{array}{c}\text { Influence of } \\
\text { Automated Queue } \\
\text { Management } \\
\text { System } \\
\text { Optimization on } \\
\text { Performance of } \\
\text { National Cement } \\
\text { Company Limited }\end{array}$ & $\begin{array}{l}\text { The study concluded } \\
\text { that reliability and } \\
\text { flexibility level; security } \\
\text { level and staff training } \\
\text { on automated Queue } \\
\text { Management systems } \\
\text { positively influence the } \\
\text { performance of the } \\
\text { National Cement } \\
\text { Company. }\end{array}$ & $\begin{array}{l}\text { The study focused on } \\
\text { the relationship } \\
\text { between automated } \\
\text { queue management and } \\
\text { organization } \\
\text { performance. The link } \\
\text { between automated } \\
\text { queuing management } \\
\text { system and employee } \\
\text { performance is not } \\
\text { brought out. }\end{array}$ \\
\hline $\begin{array}{l}\text { Cowdrey, K. } \\
\text { W., J. D. } \\
\text { Malekian, R., } \\
\text { Wanneburg, J. } \\
\text { \& Jose, A. C. }\end{array}$ & 2018 & $\begin{array}{l}\text { Applying } \\
\text { Queueing Theory } \\
\text { for the } \\
\text { Optimization of a } \\
\text { Banking Model }\end{array}$ & $\begin{array}{l}\text { The study showed that } \\
\text { using the queuing } \\
\text { methods listed in this } \\
\text { paper will reduce } \\
\text { waiting time and } \\
\text { improve customer } \\
\text { satisfaction, whilst } \\
\text { improving profits for a } \\
\text { banking firm }\end{array}$ & $\begin{array}{l}\text { The study discussed the } \\
\text { use of queuing theory } \\
\text { in improving the } \\
\text { waiting time and } \\
\text { increasing profits, } \\
\text { however, it did not link } \\
\text { the queuing theory to } \\
\text { employee performance. }\end{array}$ \\
\hline$\frac{\text { Genga Kevin }}{\text { Omondi }}$ & 2018 & $\begin{array}{c}\text { Electronic } \\
\text { queuing } \\
\text { management } \\
\text { system and } \\
\text { customer service } \\
\text { in commercial } \\
\text { banks in Kenya }\end{array}$ & $\begin{array}{l}\text { The study revealed that } \\
\text { the waiting time was } \\
\text { still a challenge as the } \\
\text { outlets were not } \\
\text { meeting the service } \\
\text { level agreement set by } \\
\text { the bank }\end{array}$ & $\begin{array}{l}\text { The study focused on } \\
\text { the link between the } \\
\text { queuing management } \\
\text { system and customer } \\
\text { service. It left out its } \\
\text { effect on employee } \\
\text { performance. }\end{array}$ \\
\hline Obe 0.0 & 2017 & $\begin{array}{c}\text { Automated } \\
\text { vehicle queuing } \\
\text { management } \\
\text { system }\end{array}$ & $\begin{array}{l}\text { This study found out } \\
\text { that the Automation of } \\
\text { queuing management } \\
\text { system showed good } \\
\text { reliability. }\end{array}$ & $\begin{array}{l}\text { This study brought out } \\
\text { the contextual gap. It } \\
\text { focused on the motor } \\
\text { vehicle sector and did } \\
\text { not link it to employee } \\
\text { performance. }\end{array}$ \\
\hline
\end{tabular}




\begin{tabular}{|c|c|c|c|c|}
\hline $\begin{array}{l}\frac{\text { Nityangini }}{\text { hhala \& }} \\
\text { Bhathwala }\end{array}$ & 2016 & $\begin{array}{l}\text { Application of } \\
\text { Queuing Theory } \\
\text { in Banking sector }\end{array}$ & $\begin{array}{l}\text { Service level } \\
\text { improvement is } \\
\text { synonymous to } \\
\text { reduction in the waiting } \\
\text { time } \\
\text { There is a correlation } \\
\text { between the levels of } \\
\text { service and the cost of } \\
\text { waiting time on the } \\
\text { queue. }\end{array}$ & $\begin{array}{l}\text { The study focused on } \\
\text { the application of } \\
\text { queuing theory on } \\
\text { customer waiting } \\
\text { time.it did not show its } \\
\text { relationship to } \\
\text { employee performance. }\end{array}$ \\
\hline $\begin{array}{l}\text { Abass Abdi } \\
\text { Mohamud }\end{array}$ & 2016 & $\begin{array}{l}\text { Automated } \\
\text { Queuing and the } \\
\text { experience of } \\
\text { Kenya } \\
\text { Commercial Bank } \\
\text { retail customers } \\
\text { In Nairobi Kenya }\end{array}$ & $\begin{array}{l}\text { The study revealed that } \\
\text { that there was a strong } \\
\text { relationship between } \\
\text { automated queuing } \\
\text { machine and customer } \\
\text { experience. } \\
\text { The study concluded } \\
\text { that the automated } \\
\text { queuing machine was of } \\
\text { considerable assistance } \\
\text { to the bank in enabling } \\
\text { it to track the customer } \\
\text { experience of all its } \\
\text { products and services } \\
\text { and to monitor the } \\
\text { traffic of knowledge in } \\
\text { its set up. }\end{array}$ & $\begin{array}{l}\text { This study linked } \\
\text { automated queuing } \\
\text { system to customer } \\
\text { experience. }\end{array}$ \\
\hline $\begin{array}{l}\text { Uddin, } \\
\text { Md.Nasir \& } \\
\text { Rashid, } \\
\text { Mahbub \& } \\
\text { Mostofa, MG \& } \\
\text { Nithe, NA. }\end{array}$ & 2016 & $\begin{array}{l}\text { Automated Queue } \\
\text { Management } \\
\text { System }\end{array}$ & $\begin{array}{l}\text { The study found out } \\
\text { that the new approach } \\
\text { of using automated } \\
\text { queuing system to } \\
\text { manage queues } \\
\text { decreases the average } \\
\text { waiting the time } \\
\text { compared to the } \\
\text { ordinary queuing } \\
\text { system }\end{array}$ & $\begin{array}{l}\text { The study compared } \\
\text { automated queue } \\
\text { management system } \\
\text { and other queuing } \\
\text { systems. }\end{array}$ \\
\hline $\begin{array}{c}\text { Agyei, W., } \\
\text { Asare-Darko, } \\
\text { C., \& Odilon, F. }\end{array}$ & 2015 & $\begin{array}{c}\text { Modeling and } \\
\text { Analysis of } \\
\text { Queuing Systems } \\
\text { in Banks }\end{array}$ & $\begin{array}{l}\text { The results of the } \\
\text { analysis of the study } \\
\text { showed using a five- } \\
\text { teller system was better } \\
\text { than a four or a six- } \\
\text { teller system in terms of } \\
\text { average waiting time } \\
\text { and the total economic } \\
\text { cost. }\end{array}$ & \\
\hline
\end{tabular}

\subsection{KNOWLEDGE GAP}

The dependent variable of each of the studies was different from the current study. However, this study will address the gaps by examining the link between the electronic queuing system on employees' performance, and well- being. The studies examined variables of the current study partially and in isolation. Further, research on the electronic queuing system in the organizational context is at its embryonic stage thus pertinence of the current study to adopt an integrated framework to unravel the conceptual, theoretical, contextual, and methodological research gaps. Most of the studies have examined the direct link between technology and employee performance thus failing to demonstrate how the electronic queuing system can influence employee performance. 


\subsection{CONCEPTUAL FRAMEWORK}

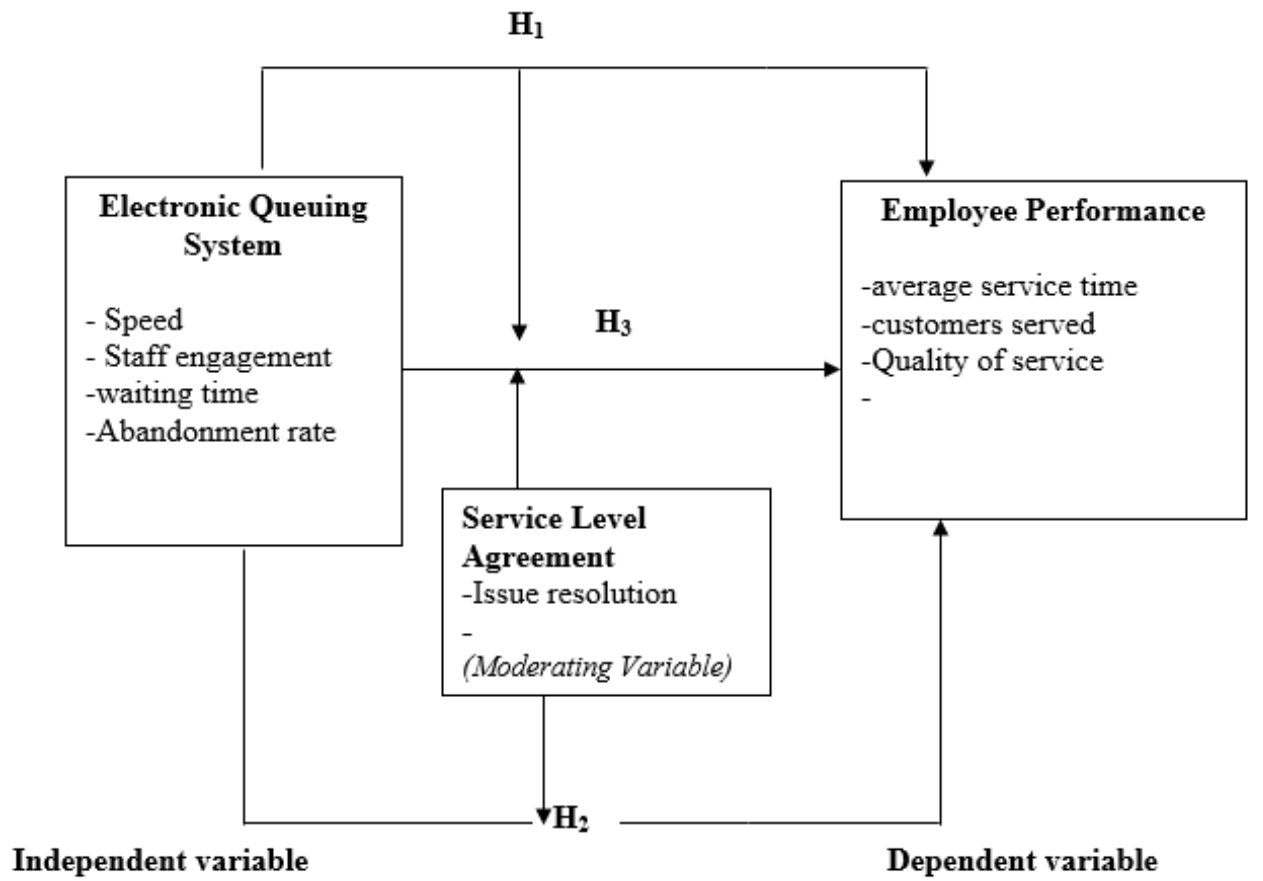

Figure 1: Conceptual Framework

\section{Research Hypotheses}

H1: There is no significant effect between electronic queuing system and employee performance.

$\mathrm{H} 2$ : There is no significant moderating effect of service level agreement on the relationship between electronic queuing system and employee performance.

H3: There is no significant joint effect of electronic queuing system and service level agreement on employee performance.

\section{REFERENCES}

Ade, E. M., Namusonge, G. S., \& Sakwa, M. (2019). Effect Of Risk Management Agility On Performance Of Savings And Credit Co-Operatives In Kenya. The Strategic Journal Of Business \& Change Management, 6(1), 150.

Agyei, W., Asare-Darko, C., \& Odilon, F. (2015). Modeling And Analysis Of Queuing Systems In Banks: (A case study of Ghana Commercial BankLtd. Kumasi Main Branch). Retrieved from http://citeseerx.ist.psu.edu/viewdoc/download?doi=10.1.1.1050.9795\&re $\mathrm{p}=\mathrm{rep} 1 \&$ type $=$ pdf

Agyei, W., Asare-Darko, C., \& Odilon, F. (2015). Modeling And Analysis Of Queuing Systems In Banks:(A Case Study Of Ghana Commercial Bank Ltd. Kumasi Main Branch). International Journal Of Scientific \& Technology Research, 4(07), 160-163. Retrieved from http://citeseerx.ist.psu.edu/viewdoc/download?doi=10.1.1.1050.9795\&re $\mathrm{p}=\mathrm{rep} 1 \&$ type $=$ pdf 
Ahmed, Sheikh. (2016). Automated Queue Management System. Global Journal Of Management And Business Research. 16. 51-58. Retrieved from https://doi.org/10.18374/RBR-16-2.6

Altman, E., Kofman, D., \& Yechiali, U. (1995). Discrete Time Queues With Delayed Information. Queueing Systems, 19(4), 361-376. Retrieved from https://doi.org/10.1007/BF01151929

Alzghoul, A., Elrehail, H., Emeagwali, O. L., \& Alshboul, M. K. (2018). Knowledge Management, Workplace Climate, Creativity And Performance : The Role Of Authentic Leadership. Journal of Workplace Learning. Retrieved from https://doi.org/10.1108/JWL-12-2017-0111

Chandra, G. \& Saraswathi, A.B.. (2018). A Study On Impact Of Performance Management System On Employee Performance With Specific Reference To Tech Mahindra, Hyderabad. International Journal of Mechanical Engineering And Technology. 9. 111-120.

Christian Swann, Simon Rosenbaum, Alex Lawrence, Stewart A. Vella, Desmond Mcewan \& Panteleimon Ekkekakis (2020): Updating Goal-Setting Theory In Physical Activity Promotion: A Critical Conceptual Review, Health Psychology Review. Retrieved from https://doi.org/10.1080/17437199.2019.1706616

Christian Swann, Simon Rosenbaum, Alex Lawrence, Stewart A. Vella, Desmond Mcewan \& Panteleimon Ekkekakis (2020): Updating Goal-Setting Theory In Physical Activity Promotion: A Critical Conceptual Review, Health Psychology Review. Retrieved from https://doi.org/10.1080/17437199.2019.1706616

Cowdrey, K. W.,J. D. Malekian, R.,Wanneburg, J. \& Jose, A. C. (2018). Applying Queueing Theory For The Optimization Of A Banking Model. Journal Of Internet Technology, 19,381-389. Retrieved from https://jit.ndhu.edu.tw/article/view/1658

Cropanzano, R., Anthony, E. L., Daniels, S. R., \& Hall, A. V. (2017). Social Exchange Theory: A Critical Review With Theoretical Remedies. Academy Of Management Annals, 11(1), 479-516. Retrieved from https://doi.org/10.5465/annals.2015.0099

Cropanzano, Russell \& Anthony, Erica \& Daniels, Shanna \& Hall, Alison. (2017). Social Exchange Theory: A Critical Review With Theoretical Remedies. The Academy Of Management Annals. Retrieved from https://doi.org/10.5465/annals.2015.0099

Dahkoul, Z. M. (2018). The Impact Of Performance Evaluation On Employee Performance, Moderating Role Of Organizational Standards. European Journal Of Business And Management, European Journal Of Business And Management. Retrieved from https://core.ac.uk/download/pdf/234628479.pdf

Dahkoul, Zuheir. (2018). The Determinants Of Employee Performance In Jordanian Organizations. Pressacademia. 5. 11-17. Retrieved from https://doi.org/10.17261/Pressacademia.2018.780

Dhar, Runu \& Chakraborty, Abhishek \& Sarkar, Jhutan. (2020). Queuing Theory And Optimization In Banking Models. Retrieved from https://doi.org/10.1007/978-981-15-1632-0_19

Diamantidis, A. D., \& Chatzoglou, P. (2019). Factors Affecting Employee Performance: An Empirical Approach. International Journal Of Productivity 


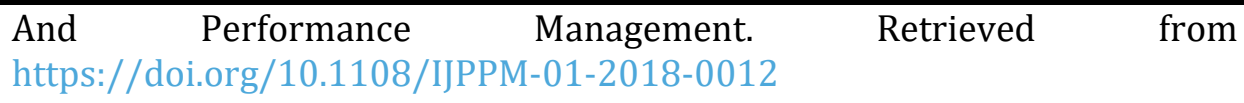

Diamantidis, Anastasios \& Chatzoglou, Prodromos. (2018). Factors Affecting Employee Performance: An Empirical Approach. International Journal of Productivity And Performance Management. Retrieved from https://doi.org/10.1108/IJPPM-01-2018-0012

Fred C. Lunenburg. (2011) Goal-Setting Theory Of Motivation, International Journal Of Management, Business, And Administration. Volume 15, Number 1.

Gitongu, M. K., Kingi, W., \& Uzel, J. M. M. (2016). Determinants Of Employees' Performance Of State Parastatals In Kenya : A Case Of Kenya Ports Authority.

Isaac, O., Abdullah, Z., Ramayah, T., \& Mutahar, A. M. (2017). Internet Usage, User Satisfaction, Task-Technology Fit, And Performance Impact Among Public Sector Employees In Yemen. The International Journal Of Information And Learning Technology. Retrieved from https://doi.org/10.1108/IJILT-112016-0051

Ismail, Iqbal, \& Nasr (2019).

Jahan, N. And Kim, S.W. (2020), "Understanding Online Community Participation Behavior And Perceived Benefits: A Social Exchange Theory Perspective", PSU Research Review, Vol. Ahead-Of-Print No. Ahead-Of-Print. Retrieved from https://doi.org/10.1108/PRR-12-2019-0036

Jahan, N., \& Kim, S. W. (2020). Understanding Online Community Participation Behavior And Perceived Benefits: A Social Exchange Theory Perspective. PSU Research Review. Retrieved from https://doi.org/10.1108/PRR-122019-0036

Jonatan Sahlin \& Jannis Angelis , Femi Olan (Reviewing Editor) (2019) Performance Management Systems: Reviewing The Rise Of Dynamics And Digitalization, Cogent Business \& Management, 6:1. Retrieved from https://doi.org/10.1080/23311975.2019.1642293

K. L. Hartley, (2005) "Defining Effective Service Level Agreements For Network Operation And Maintenance," In Bell Labs Technical Journal, Vol. 9, No. 4, Pp. 139-143. Retrieved from https://doi.org/10.1002/bltj.20067

Kasimu Sendawula, Saadat Nakyejwe Kimuli, Juma Bananuka \& Grace Najjemba Muganga, (2018). Training, Employee Engagement And Employee Performance : Evidence From Uganda's Health Sector, Cogent Business \& Management, $\quad 5: 1, \quad 1470891 . \quad$ Retrieved from https://doi.org/10.1080/23311975.2018.1470891

Kiplagat, J., Kamaku, P. W. \& Paul, S. N. (2020). Influence Of Automated Queue Management System Optimization On Performance Of National Cement Company Limited. International Academic Journal Of Information Systems And Technology, 2(1), 221-244. Retrieved from http://www.iajournals.org/articles/iajist_v2_i1_221_244.pdf

Kiplagat, J., Kamaku, P. W. \& Paul, S. N. (2020). Influence Of Automated Queue Management System Optimization On Performance Of National Cement Company Limited. International Academic Journal Of Information Systems And Technology, 2(1), 221-244. Retrieved from http://www.iajournals.org/articles/iajist_v2_i1_221_244.pdf

Kiplagat, J., Kamaku, P. W., \& Paul, S. N. A. (2020). Influence Of Automated Queue Management System Optimization On Performance Of National Cement Company Limited. International Academic Journal Of Information Systems 


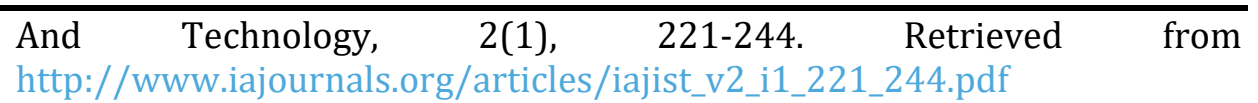

Legato, P. And Mazza, R.M. (2019), "Queueing Analysis For Operations Modeling In Port Logistics", Maritime Business Review, Vol. 5 No. 1, Pp. 67-83. Retrieved from https://doi.org/10.1108/MABR-09-2019-0035

Madadi, Najmeh \& Haghighian Roudsari, Arousha \& Wong, Kuan \& Rahiminezhad Galankashi, Masoud. (2013). Modeling And Simulation Of A Bank Queuing System. Proceedings of International Conference On Computational Intelligence, Modelling And Simulation. Retrieved from https://doi.org/10.1109/CIMSim.2013.41

Men, L. R. (2015). Employee Engagement In Relation To Employee-Organization Relationships And Internal Reputation: Effects Of Leadership Communication. Journal Of Public Relations, 9, 1942-4604.

Mohamud, A. A. (2016). Automated Queuing And The Experience Of Kenya Commercial Bank Retail Customers In Nairobi Kenya (Doctoral Dissertation, University Of Nairobi). Retrieved from http://41.204.161.209/handle/11295/97200

Mubeen, Saad \& Abbaspour Asadollah, Sara \& Papadopoulos, Alessandro \& Ashjaei, Mohammad \& Pei Breivold, Hongyu \& Behnam, Moris. (2017). Management Of Service Level Agreements For Cloud Services In Iot: A Systematic Mapping Study. IEEE Access. Retrieved from https://doi.org/10.1109/ACCESS.2017.2744677

Mwangi S. K, Ombuni M. T. (2015). An Empirical Analysis Of Queuing Model And Queuing Behaviour In Relation To Customer Satisfaction At Jkuat Students Finance Office. American Journal of Theoretical And Applied Statistics. Retrieved from https://doi.org/10.11648/j.ajtas.20150404.12

Obe. 0.0., (2017). Automated Vehicle Queuing Management System, International Journal Of Scientific \& Engineering Research, 8(8), 646-649

PAAIS, M., \& PATTIRUHU, JR (2020). Effect Of Motivation, Leadership, And Organizational Culture On Satisfaction And Employee Performance. The Journal Of Asian Finance, Economics, And Business , 7 (8), 577-588. Retrieved from https://doi.org/10.13106/jafeb.2020.vol7.no8.577

Paais, M., \& PATTIRUHU, J. R. (2020). Effect Of Motivation, Leadership, And Organizational Culture On Satisfaction And Employee Performance. The Journal Of Asian Finance, Economics, And Business, 7(8), 577-588. Retrieved from https://doi.org/10.13106/jafeb.2020.vol7.no8.577

Peter, Peter \& R, Sivasamy. (2019). Queuing Theory Techniques And Its Real Applications To Health Care Systems - Outpatient Visits. International Journal of Healthcare Management. Retrieved from https://doi.org/10.1080/20479700.2019.1616890

Ravi Chandra, G., \& Saraswathi, D. A. (2018). A Study On Impact Of Performance Management System On Employee Performance With Specific Reference To Tech Mahindra, Hyderabad. International Journal of Mechanical Engineering And Technology, 9(10), 111-120.

Sammy Kariuki Mwangi, Thomas Mageto Ombuni.(2015) An Empirical Analysis of Queuing Model And Queuing Behavior In Relation To Customer Satisfaction At Jkuat Students Finance Office. American Journal of Theoretical And Applied Statistics. Vol. 4, No. 4, 2015, Pp. 233-246. Retrieved from https://doi.org/10.11648/j.ajtas.20150404.12 
Sarker, M. M., Shah, Md. A. I., Akhund, T. Md. N. U., \& Uddin, Md. S. (2016). An Approach Of Automated Electronic Voting Management System For Bangladesh Using Biometric Fingerprint. International Journal Of Advanced Engineering Research And Science, 3(11), 64-70. Retrieved from https://doi.org/10.22161/ijaers/3.11.11

Shah, N., Irani, Z., \& Sharif, A. M. (2017). Big Data In An HR Context: Exploring Organizational Change Readiness, Employee Attitudes And Behaviors. Journal of Business Research, 70, 366-378. Retrieved from https://doi.org/10.1016/j.jbusres.2016.08.010

Tasar, B.Ventura, K.Çiçekli, U.(2020)A Simulation Model For Managing Customer Waiting Time In Restaurants: Scenarios And Beyond.British Food Journal,122,2881-2894. Retrieved from https://doi.org/10.1108/BFJ-092019-0685

Titarmare, N., \& Yerlekar, A. (2018). A Survey On Patient Queue Management System. International Journal Of Advanced Engineering, Management And Science, $\quad 4(4)$, 239985. Retrieved from https://doi.org/10.22161/ijaems.4.4.3

Uddin, M. N., Rashid, M., \& Mostafa, M. (2016). Automated Queue Management System. Global Journal Of Management And Business Research.

Uddin, Md. Nasir \& Rashid, Mahbub \& Mostofa, MG \& Nithe, NA. (2016). Automated Queue Management System. Global Journal Of Management And Business Research. Retrieved from https://doi.org/10.18374/RBR-16-2.6

Varela, Martín \& Zwickl, Patrick \& Reichl, Peter \& Xie, Min \& Schulzrinne, Henning. (2015). From Service Level Agreements (SLA) To Experience Level Agreements (ELA): The Challenges Of Selling Qoe To The User. Retrieved from https://doi.org/10.1109/ICCW.2015.7247432

Varela, Martín \& Zwickl, Patrick \& Reichl, Peter \& Xie, Min \& Schulzrinne, Henning. (2015). From Service Level Agreements (SLA) To Experience Level Agreements (ELA): The Challenges Of Selling Qoe To The User. Retrieved from https://doi.org/10.1109/ICCW.2015.7247432

Yurtkoru, E. S., Bozkurt, T., Bekta, F., Ahmed, M. J., \& Vehap, K. O. L. A. (2017). Application Of Goal Setting Theory. Pressacademia Procedia, 3(1), 796-801. Retrieved from https://doi.org/10.17261/Pressacademia.2017.660 